УДК: 378.014

DOI:

Людмила Мацук, кандидат педагогічних наук,

доиент кафедри теорії та методики дошкільної і спеціальної освіти

ДВНЗ “Прикарпатський національний університет імені Василя Стефаника"

Олександра Кузенко, кандидат педагогічних наук, доцент кафедри українознавства і філософії,

Івано-Франківського національного медичного університету

Петро Кузенко, кандидат мистецтвознавства, доцент кафедри образотворчого і декоративно-прикладного мистецтвва та реставраціі Навчально-наукового Інституту мистецтв ДВНЗ “Прикарпатський національний університет імені Василя Стефаника"

\title{
СТВОРЕННЯ ІННОВАЦІЙНОГО ОСВІТНЬОГО СЕРЕДОВИЩА В КОНТЕКСТІ МОДЕРНІЗАЦЇ̈ ЗВО УКРАЇНИ
}

У статті розглянуто основні аспекти створення інновачійного освітнього середовищя в контексті модернізації ЗВО України. Акиентується, щзо завдяки изьому напряму модернізаиії ЗВО відбуваються якісні зміни в результатах освітньої діяльності, створюються удосконалені форми освітньої діяльності здобувачів вищої освіти. Використання інноваційних освітніх технологій в професійній підготовиі забезпечують формування професійно важливих компетентностей особистості шляхом організації науково-дослідницьких й навчально-методичних проєктів; ознайомлення та впровадження кращого вітчизняного та європейського та досвіду в галузі освіти; організації та проведенні конференцій, семінарів, “круглих столів”, тренінгових курсів; використанню в усіх видах освітньої діяльності IT-технологій.

Ключові слова: інноваційні технологї; інноваційне освітне середовище; заклад вищої освіти; модернізація освітнього процесу; професійна компетентність педагога; Болонський процес.

Jim. 15.

Lyudmyla Matsuk, Ph.D.(Pedagogy), Associate Professor of the Theory and Methods of Preschool and Special Education Department State Higher Educational Institution "Vasyl Stefanyk Precarpathian National University" Olexandra Kuzenko, Ph.D. (Pedagogy), Associate Professor of the Ukrainian Studies and Philosophy Department of Ivano-Frankivsk National Medical University

Petro Kuzenko, Ph.D. (Art History), Associate Professor of the Fine and Decorative Arts and Restoration Department Educational and Scientific Institute of Arts,

State Higher Educational Institution "Vasyl Stefanyk Precarpathian National University"

\section{CREATION OF INNOVATIVE EDUCATIONAL ENVIRONMENT IN THE CONTEXT OF MODERNIZATION OF HIGHER EDUCATION INSTITUTIONS OF UKRAINE}

In the article the main aspects of creating an innovative educational environment in the context of modernization of higher education establishments in Ukraine are examined. It is emphasized that due to this tendency of modernization of higher education institutions the conditions for personal and professional development of future specialists are provided, qualitative changes of their educational results take place. In this regard, in the theory and practice of modern pedagogical science intensified research aimed at exploring the content and optimal ways of implementing innovations in the educational space are taking place. An innovative educational environment is considered as a well-organized from a pedagogical point of view environment, promoting the development of innovative resources of the individual and an integrated means of accumulation and realization of innovative potential of the educational institution. The main components of the innovation environment are: strategy of modernization of the educational process, tactics of formation of innovation processes, the content of the innovation environment, organizational support of the innovation environment (operational management technologies), providing the development of educational institutions. These elements interact with each other completing the educational environment with their features, creating a single innovative structure, which is the basis for the development of the teachers' professional competence.

A necessary condition for the functioning of an innovative educational environment in the higher education institution is the use of the latest technologies, the creation of subject-oriented information environment. Their use in professional training provides the formation of professionally important personal competencies by means of 


\section{СТВОРЕННЯ ІННОВАЦЙНОГООСВІТНЬОГОСЕРЕДОВИЩА В КОНТЕКСТІМОДЕРНІЗАЦЇ̈ЗВО УКРАЇНИ}

organization of research and methodological teaching projects; introduction of the best domestic and European experience in the field of education; organization and holding of conferences, seminars, round tables, training courses; use of IT technologies in all types of educational activities.

Thus, an organizational and pedagogical support of the educational process in higher education institutions is aimed at mastering modern innovative pedagogical technologies, which is due to the focus on European and world educational standards, development of multilevel educational system, functioning of modern information technologies, and wide usage of the Internet, creation of educational and methodical complexes, wide spread of research and experimental work on approbation of updated educational programs and curricula taking into account the Standard of Higher education (if available), creation of author's textbooks, manuals, new management structures, etc. The implementation of these innovative pedagogical technologies in the process of future professionals training is one of the ways of implementing of a personality-oriented approach and improving of the educational process in higher education establishments.

Keywords: innovative technologies; innovative educational environment; higher education institution; modernization of the educational process; professional competence of the teacher; Bologna process.

П остановка проблеми. На сучасному етапі розвитку вищої освіти України пріоритетного значення набуває створення інноваційного освітнього середовища, максимально сприятливого для розвитку індивідуальних здібностей, творчих обдарувань здобувачів освіти, формування їх фахової компетентності та професійної культури загалом. У зв'язку з цим у теорії та практиці сучасної педагогічної науки активізувалися пошуки, спрямовані на дослідження змісту й оптимально ефективних шляхів впровадження інновацій в освітній простір інституцій різних рівнів освіти $[13$ 125].

Пріоритетність формування інноваційного освітнього середовища відображено в сучасних законодавчих та нормативних документах, які регламентують здійснення інноваційної діяльності: закони України "Про інноваційну діяльність", “Про пріоритетні напрями інноваційної діяльності в Україні”, накази Міністерства освіти і науки України "Про внесення змін до Положення про експериментальний загальноосвітній навчальний заклад”, “Про внесення змін до Положення про порядок здійснення інноваційної освітньої діяльності”, “Стратегія інноваційного розвитку України на 2010-2020 рр. в умовах глобалізаційних викликів" та інші.

Так, у Законі України “Про освіту” зазначено, що мета освіти - це всебічний розвиток людини як особистості та найвищої цінності суспільства, розвиток їі талантів, розумових і фізичних здібностей, виховання високих моральних якостей, формування громадян, здатних до свідомого суспільного вибору, збагачення на цій основі інтелектуального, творчого, культурного потенціалу народу, підвищення освітнього рівня народу, забезпечення народного господарства кваліфікованими фахівцями [5].

Відповідно, у “Національній доктрині розвитку освіти України у XXI ст.” наголошено, що основним пріоритетом української системи освіти $\epsilon$ створення умов для розвитку самореалізаціі кожної особистості як громадянина України, формування покоління, здатного навчатися упродовж життя, формування цінностей громадянського суспільства [11].

Аналіз попередніх досліджень. Визначення шляхів розвитку інноваційного закладу як відкритої соціально-педагогічної системи та чинника особистісного розвитку здобувача освіти знайшли відображення в працях багатьох українських дослідників. Важливе місце впровадження освітніх інновацій, інноваційному розвитку освітніх систем та інноваційних процесів відводиться у роботах провідних українських учених І. Беха, Н. Бібік, Л. Ващенко, Л. Даниленко та ін.

Теоретико-методологічною основою для визначення сутності поняття "освітне середовище" виступають концепції сучасних дослідників, які розглядають різноманітні аспекти категорії “середовище” (Л. Буєва, Ю.Мануйлов, Л. Новикова, Н. Селиванова, В. Петровський, I. Якиманська, В. Ясвін та ін.); сутність понять “навчально-терапевтичне середовище”(Г.Любимова); “уклад життя школи” (О. Тубельський); “атмосфера школи”, “корпоративний дух школи”, “організаційний клімат школи” (О. Гуменюк); “освітній простір” (А. Валицька, І. Фрумін, Б. Ельконін); “виховний простір”, “виховна система" (Л. Новикова, Н. Селиванова та ін.); “творче освітнє середовище" (В. Ясвін). Дослідник С. Микитюк розглядає середовище як чинник розвитку особистості [10].

Мета статті. Висвітлення основних аспектів створення інноваційного освітнього середовища в контексті модернізації ЗВО України.

Аналіз результатів численних досліджень свідчить, що поняття "освітнє середовище" розглядається у різних значеннях як:

1) взаємодія освітніх закладів, сім'ї, позашкільних державних та громадських установ, інформаційно-культурного середовища; 


\section{СТВОРЕННЯ ІННОВАЦЙНОГООСВІТНЬОГОСЕРЕДОВИЩА В КОНТЕКСТІМОДЕРНІЗАЦЇ̈ЗВОУКРАЇНИ}

2) сукупність матеріальних вимог у відповідності 3 педагогічними, ергономічними, санітарногігієнічними вимогами до освітнього процесу;

3) різноманітний, різнорівневий світ, який оточує людину, формує її уявлення про довкілля, ставлення до людей та навколишньої дійсності [14].

Узагальнення різноманітних підходів до визначення поняття “освітнє середовище” та комплексу споріднених педагогічних явищ дає підставу визначити освітнє середовище сучасного закладу освіти як сукупність духовноматеріальних умов його функціонування, що забезпечують саморозвиток вільної й активної особистості, реалізацію її творчого потенціалу. Освітнє середовище виступає функціональним і просторовим об'єднанням суб'єктів освіти, між якими встановлюються тісні різнопланові групові взаємозв'язки і може розглядатися як модель соціокультурного простору, у якому відбувається становлення особистості [15].

Серед нових підходів до сучасного освітнього середовища фахівці визначають:

-гуманістичний-відображає людиноцентристський підхіддо розвитку сучасного соціального оточення, гармонізацію педагогічних і соціальних відносин, формування у педагогів духовної та педагогічної культури;

- акмеологічний - дає змогу обгрунтувати закономірності творчого розвитку учасників освітнього середовища;

- системний - має на меті модернізацію освітнього процесу, встановлення зв'язків між різними його компонентами та визначення освітнього середовища як цілісної системи, яка формує фахівця;

- інформаційний - забезпечує достатній рівень інформаційної культури педагогів, сприяє підвищенню ефективності професійної підготовки педагогічних кадрів шляхом упровадження в практику роботи сучасних педагогічних i цифрових технологій;

- технологічний - спрямований на активне використання інноваційних технологій, удосконалення традиційного освітнього процесу шляхом поопераційного застосування системи дій, операцій або процедур, грунтованих на нових досягненнях науки, які гарантують досягнення більш високого рівня навченості та вихованості;

-компетентнісний - акцентує увагу на вкрай важливому та сучасному розумінні професійнокомпетентнісних засад педагогів, спроможних самостійно і творчо розв'язувати професійні завдання, усвідомлювати особисту і суспільну значущість управлінської та педагогічної діяльності, відповідати за їі результати, сприяти соціальній стабільності й розвитку суспільства. Їх діяльність спрямована також на набуття додаткових компетентностей, у тому числі й дослідницьких, що дає змогу успішно діяти в проєктах різного масштабу, у тому числі й міжнародного;

- інноваційний - сприяє створенню інноваційнотворчої атмосфери, формуванню у педагогів готовності до інноваційної професійної діяльності.

Реалізація означених підходів, визначає необхідність створення інноваційного освітнього середовища [9, 46]. Інноваційне освітне середовище - це педагогічно доцільно організований простір життєдіяльності, який сприяє розвитку інноваційного ресурсу особистості; інтегрований засіб накопичення і реалізації інноваційного потенціалу закладу освіти.

Основними складовими інноваційного середовища є: стратегія модернізації освітнього процесу, тактика формування інноваційних процесів, зміст інноваційного середовища, організаційне забезпечення розвитку інноваційного середовища (операційні управлінські технологіi), прогнозування розвитку закладів освіти [2]. Ці елементи взаємодіють між собою та наповнюють освітнє середовище своїми особливостями та створюючи єдину інноваційну структуру, яка виступає основою розвитку професійної компетентності педагогів.

У формуванні інноваційного освітнього середовища важливе значення відводиться матеріально-технічному забезпеченню, яке передбачає наявність спеціальної інфраструктури. До неї поруч із закладами освіти входять науковометодичні установи, бібліотеки, інформаційні центри, соціокультурні організації. Означені інституції надають допомогу закладу освіти в реалізації інноваційних проєктів $[1,81]$.

Необхідною умовою функціонування інноваційного освітнього середовища в ЗВО $є$ використання новітніх технологій, створення предметно-орієнтованого, інформаційного середовища, що дозволить використовувати мультимедіа, електронні підручники, низку платформ для дистанційної освіти (GoogleClassroom, Moodle, Edmodo, Мій клас, Classdojo та ін.) [12], вебінари, онлайн-курси тощо; освоєння засобів комунікації (комп’ютерної мережі, телефонного, телевізійного, супутникового зв'язку для обміну інформацією); навчання правил і навичок “навігації” в інформаційному просторі; підключення до системи освітніх бібліотечно інформаційних центрів - медіатек.

Успішне функціонування інноваційного 


\section{СТВОРЕННЯ ІННОВАЦЙНОГООСВІТНЬОГОСЕРЕДОВИЩА В КОНТЕКСТІМОДЕРНІЗАЦІЇЗВОУКРАЇНИ}

освітнього середовища забезпечується завдяки створенню умов для самонавчання, збереженню традицій при постійному введенні новацій, актуалізації потенційних можливостей усіх мікросередовищ 3ВО $[6,56]$. При визначенні критеріїв ефективності функціонування інноваційного освітнього середовища враховуються, розроблені в науковій літературі критерії організаційно-педагогічного характеру (В. Ясвін, Б. Чижевський, В. Шаркунова), ефективності й результативностідіяльності(Л.Колесникова,Н.Побєда, Т. Семенюк, С. Шишов та ін.). Однак означені критерії мають нормативний характер і не враховують потенційних можливостей саморозвитку й самооновлення закладу освіти.

Відтак А. Каташовий запропонував систему критеріїв інноваційного освітнього середовища сучасного закладу вищої освіти на основі культурологічних та психолого-педагогічних концепцій динамічного розвитку складних систем і утворень, що включає:

1) можливості освітнього середовища забезпечити полікультурний розвиток молоді;

2) рівень загальнотеоретичної й спеціальної підготовки; результативність творчої та науководослідницької діяльності здобувачів освіти, динаміка розвитку інтелекту особистості за період перебування у даному середовищі;

3) наповненість освітнього середовища духовним змістом;

4) створення умов для самореалізації особистості у творчій діяльності;

5) здатність освітнього середовища задовольнити весь комплекс потреб особистості та сформувати в неї систему соціальних і духовних цінностей, що забезпечать успішну адаптацію до сучасної соціокультурної ситуації;

6) рівень естетизації освітнього середовища, естетична виразність;

7) здатність до саморозвитку й самооновлення, ефективність використання наявних освітніх ресурсів $[7,9]$.

Широко впроваджується у сучасних закладах вищої освіти України така інноваційна форма організації освітнього процесу, як рейтингова система контролю й оцінки знань студентів, що $\epsilon$ важливою складовою інноваційного освітнього простору. Пріоритетним завданням упровадження рейтингової системи оцінювання знань студентів стало підвищення якості знань шляхом активізації освітньої діяльності, активізація самостійної роботи студентів, забезпечення об'єктивності оцінки знань, виявлення індивідуальних здібностей студентів, а також мотивація пізнавальної діяльності молодих людей за умови здорової конкуренції, націленої на здобуття більш високого місця у рейтинговому списку групи, спеціальності, факультету. Ця система $є$ важливим фактором впровадження кредитно-модульної системи, відповідно до вимог Болонського процесу [4, 340 341].

Важливим чинником інновації в закладах вищої освіти стала розробка авторських курсів, які можуть бути застосовані як для індивідуального навчання обдарованих студентів, так i, за умов наявності матеріальної бази, для широкого використання.

Новітньою інноваційною формою організації навчальної діяльності студентів у багатьох зарубіжних закладах освіти стали, так звані, гібридні курси (hybridcourses) - поєднання очного і дистанційного навчання, ще передбачає самостійне опанування студентами окремих курсів в електронному форматі, що не виключає його безпосередніх контактів 3 викладачем. Впровадження дистанційного навчання студентів стаціонарної форми навчання базується на оновленому розумінні змісту поняття “дистанціювання студента від викладача”. За цієі умови пріоритетне значення належить не фізичному, а педагогічному аспекту феномену дистанціювання, яке тлумачиться як можливість забезпечення більшої автономності студента, що уможливлює суттєве поліпшення організації самостійної роботи $[3,6]$.

Інноваційність дистанційної освіти забезпечується тим, що iï інформаційно-аналітична система представлена навчально-методичним комплексом: підручник; навчальний посібник для самостійного вивчення матеріалу; конспект лекцій; розробка практичних, лабораторних занять, тематика курсових робіт, презентацій, творчих проєктів; довідкова література. Так формуються - дві підсистеми: мультимедійний комплекс теоретичного матеріалу, практичних занять, лабораторних робіт і розв'язання проблем у прикладному програмуванні та інформаційна система аналізу процесу освіти і ступеня засвоєння матеріалу [8].

Навчально-методичний комплекс також містить систему методів, контролю й аналізу освітнього процесу з оцінкою рівня засвоєння матеріалу і підготовкою методичних рекомендацій щодо його організації. Для цього передбачено багаторівневе тестування з усіх видів роботи. Структурними елементами цілісного курсу дистанційного навчання може бути набір модульних блоків з окремих розділів, що мають свій рейтинг і впливають на підсумкову оцінку знань студентів. До складу всіх дидактичних 


\section{СТВОРЕННЯ ІННОВАЦЙНОГО ОСВІТНЬОГОСЕРЕДОВИЩА В КОНТЕКСТІ МОДЕРНІЗАЦЇ̈ЗВОУКРАЇНИ}

одиниць входять: інформаційний блок, тобто теоретична складова, сформована на основі гіпертекстових технологій, статичного та динамічного графічного матеріалу, завдання для самостійної роботи, а також контрольні запитання та тестові завдання $[3,7]$.

Упровадження в освітній процес закладів вищої освіти сучасних інноваційних технологій надає викладачам функцій консультанта, фасилітатора, наставника, що вимагає від нього спеціальної психолого-педагогічної підготовки, з огляду на те, що в його професійній діяльності реалізуються не тільки спеціальні предметні знання, але й сучасні знання з різних галузей науки.

Висновки 3 даного дослідження i перспективи подальших розвідок. Таким чином, організаційно-педагогічне забезпечення освітнього процесу в закладах вищої освіти спрямоване на опанування сучасними інноваційними педагогічними технологіями, що відбувається завдяки орієнтації на європейські та світові освітні стандарти, розвиток багаторівневої освітньої системи, функціонування в 3 ВО сучасних інформаційних технологій, широке включення до системи Internet, створення навчально-методичних комплексів, поширення дослідницько-експериментальної роботи 3 апробації оновлених освітніх програм та навчальних планів з урахуванням Стандарту вищої освіти (за наявності), створення авторських підручників, посібників, нових структур управління тощо. Реалізація означених інноваційних педагогічних технологій у підготовці майбутніх фахівців є одним 3 шляхів упровадження особистісноорієнтованого підходу та удосконалення освітнього процесу в ЗВО.

\section{ЛІТЕРАТУРА}

1. Бачинська С. М. Механізм формування інноваційного освітнього простору в регіоні. Педагогіка і психологія. 2007. № 1 (54). С. 79-88.

2. Ващенко Л. Рівні розвитку інноваційного середовища. URL: http: // osvita.ua / school / method /1934/

3. Дубасенюк О.А. Інноваційні освітні технології та методики в системі професійнопедагогічної підготовки. Професійна педагогічна освіта: інноваційні технологї та методики: Монографія / За ред. О. А. Дубасенюк. Житомир: Вид-во ЖДУ ім. І. Франка, 2009. С. 14-47.

4. Енциклопедія освіти / Акад. пед. наук України ; гол. ред. В. Г. Кремень. Київ : Юрінком Інтер, 2008. $1040 \mathrm{c}$.

5. Закон України “Про освіту”. URL: http:// zakon2.rada.gov.ua/laws/show/1060-12
6. Каташов А. І. Ліцей у ліцеї. Директор школи, лічею, гімназії. 2000. № 1. С. 55-62.

7. Каташов А. І. Педагогічні основи розвитку інноваційного освітнього середовища сучасного ліцею: автореф. дис. ...канд. пед. наук: 13.00.01. Луган. держ. пед. ун-т ім. Т. Шевченка, Нац. пед. ун-т ім. М. П. Драгоманова. Луганськ, 2001. 20 с.

8. Мацук Л.О. Використання інноваційних технологій в контексті впровадження сучасних концепцій розвитку педагогічної освіти в Україні. Збірник наукових праць національної академіі Державної прикордонної служби Украӥни. Серія: Педагогічні науки / гол.ред. О.В.Діденко. Хмельницький: Видавництво НАДПСУ, 2019. №1 (16). С. 299-312.

9. Мельник Н. А. Нові форми впровадження та поширення педагогічного досвіду як важлива умова створення інноваційного освітнього середовища. Управління школою. 2009. № 36 (408). С. 45-56.

10.Микитюк С. О. Освітнє середовище як ресурс якості підготовки педагогів у BH3. URL: http://archive.nbuv.gov.ua/portal/soc_gum/pednauk/ 2012_6/308.pdf

11. Національна доктрина розвитку освіти. URL: http://zakon3.rada.gov.ua/laws/show/347/2002).

12. Осадча К., Осадчий В., Спірін О., Круглик В. Реалізація індивідуалізації та персоналізації навчання засобами MOODLE. Молодь і ринок. №1 (187). 2021. С.38-43.

13. Ткачук Н. Інноваційне освітнє середовище як умова розвитку професійної компетентності педагогів. Науковий вісник Східноєвропейського національного університету імені Лесі Украӥнки. Луцьк, 2015. № 1 (32). С. 124-129.

14.Шапран O.I., Шапран Ю.П. Створення інноваційного освітнього середовища в процесі професійної підготовки майбутнього вчителя. URL: https://www.sportpedagogy.org.ua $/ \mathrm{html} /$ journal/2010-09/10soitpt.pdf.

15.Яблонь Л.С., Кузенко О.Й. Актуальні проблеми розвитку педагогічної майстерності сучасного фахівця. Освітні обрії.Том2(51), 2020. C. $147-150$.

\section{REFERENCES}

1. Bachynska, Y. M. (2007). Mekhanizm formuvannia innovatsiinoho osvitnoho prostoru $\mathrm{v}$ rehioni [The mechanism of formation of innovative educational space in the region]. Pedagogy and Psychology. No. 1 (54). pp. 79-88. [in Ukrainian].

2. Vashchenko, L. Rivni rozvytku innovatsiinoho seredovyshcha [Levels of development of the innovation environment]. Available at: http: // osvita.ua / school / method /1934 /[in Ukrainian]. 


\section{СТВОРЕННЯ ІННОВАЦЙНОГООСВІТНЬОГОСЕРЕДОВИЩА В КОНТЕКСТІМОДЕРНІЗАЦЇ̈ЗВОУКРАЇНИ}

3. Dubaseniuk, O.A. (2009). Innovatsiini osvitni tekhnolohii ta metodyky v systemi profesiinopedahohichnoi pidhotovky [Innovative educational technologies and methods in the system of professional and pedagogical training]. Professional pedagogical education: innovative technologies and methods: Monograph. (Ed.). O.A. Dubaseniuk. Zhytomyr, pp. 14-47. [in Ukrainian].

4. Entsyklopediia osvity (2008). [Encyclopedia of Education]. Acad. of Ped. Sciences of Ukraine; (Ed.). V.Kremin. Kyiv, 1040 p. [in Ukrainian].

5.Zakon Ukrainy "Pro osvitu" [Law of Ukraine "On Education"]. Available at: //zakon2.rada.gov.ua/ laws/show/1060-12 [in Ukrainian].

6. Katashov, A. I. (2000). Litsei u litsei [Lyceum in lyceum]. Director of school, lyceum, gymnasium. No. 1. pp. 55-62. [in Ukrainian].

7. Katashov, A. I. (2001). Pedahohichni osnovy rozvytku innovatsiinoho osvitnoho seredovyshcha suchasnoho litseiu [Pedagogical bases of development of the innovative educational environment of modern lyceum]. Extended abstract of candidatejs thesis. T. Shevchenko Lugansk State Ped. Univ., Nat. Ped. Univ. named after Dragomanov. Luhansk, 20 p. [in Ukrainian].

8. Matsuk, L.O. (2019). Vykorystannia innovatsiinykh tekhnolohii v konteksti vprovadzhennia suchasnykh kontseptsii rozvytku pedahohichnoi osvity v Ukraini [Use of innovative technologies in the context of introduction of modern concepts of development of pedagogical education in Ukraine]. Collection of scientific works of the National Academy of the State Border Guard Service of Ukraine.Series: Pedagogical sciences. (Ed.). O.V.Didenko. Khmelnytsky, No. 1 (16). pp. 299-312. [in Ukrainian].

9. Melnyk, N.A. (2009). Novi formy vprovadzhennia ta poshyrennia pedahohichnoho dosvidu yak vazhlyva umova stvorennia innovatsiinoho osvitnoho seredovyshcha [New forms of introduction and dissemination of pedagogical experience as an important condition for creating an innovative educational environment]. School management. No. 36 (408). pp. 45-56. [in Ukrainian].

10. Mykytiuk, S. O. Osvitnie seredovyshche yak resurs yakosti pidhotovky pedahohiv u VNZ [Educational environment as a resource for the quality of teacher training in universities]. Available at: http:/ /archive.nbuv.gov.ua/portal/soc_gum/pednauk/ 2012_6/308.pdf [in Ukrainian].

11. Natsionalna doktryna rozvytku osvity [National doctrine of education development]. Available at: http:/ /zakon3.rada.gov.ua/laws/show/347/2002). [in Ukrainian].

12. Osadcha, K., Osadchyi, V., Spirin, O. \& Kruhlyk, V. (2021). Realizatsiia indyvidualizatsii ta personalizatsii navchannia zasobamy MOODLE [Implementation of individualization and personalization of training by means of MOODLE]. Youth and the Market. No.1 (187). pp.38-43. [in Ukrainian].

13. Tkachuk, N. (2015). Innovatsiine osvitnie seredovyshche yak umova rozvytku profesiinoi kompetentnosti pedahohiv [Innovative educational environment as a condition for the development of professional competence of teachers]. Scientific Bulletin of Lesia Ukrainka East European National University. Lutsk, No.1 (32). pp. 124-129. [in Ukrainian].

14. Shapran, O.I. \& Shapran, Y.P. Stvorennia innovatsiinoho osvitnoho seredovyshcha v protsesi profesiinoi pidhotovky maibutnoho vchytelia [Creating an innovative educational environment in the process of professional training of future teachers]. Available at: https://www.sportpedagogy.org.ua/html/journal/ 2010-09/10soitpt.pdf. [in Ukrainian].

15. Yablon, L.S. \& Kuzenko, O.I. (2020). Aktualni problemy rozvytku pedahohichnoi maisternosti suchasnohofakhivtsia [Actual problems of development of pedagogical skill of the modern expert]. Educational horizons. No.2(51). pp.147150. [in Ukrainian].

Стаття надійшла до редакції 17.03.2021

\section{G58089⿻2}

"Успіх приходить лише до тих, хто не залишає спроб домогтися свого і незмінно має позитивне світосприйняття".

Вільям Клемент Стоун американсьқий бізнесмен, меценат

"З усіх дарів провидіння самий милосердний ідорогоиінний-наше незнання того, що нас чеқає nonepedy".

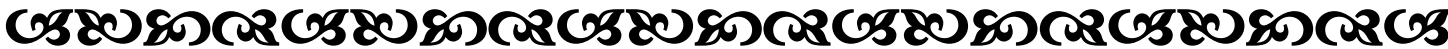

